\title{
Temperature dependence of phosphate sorption in mineral soils
}

\author{
RAINA NISKANEN \\ University of Helsinki, Department of Agricultural Chemistry, \\ SF-00710 Helsinki, Finland
}

\begin{abstract}
The sorption of phosphate was studied in 33 mineral soil samples at the temperatures of $+5^{\circ} \mathrm{C}$ and $+20^{\circ} \mathrm{C}$. The soils were equilibrated for 2 days with a solution containing phosphate $0.1 \mathrm{mmol} / 1$ at an ionic strength of 0.01 . At $+5^{\circ} \mathrm{C}$, the sorption remained unchanged or increased slightly as compared to the sorption at $+20^{\circ} \mathrm{C}$. The differences between sorbed amounts ranged from -0.03 to $0.29 \mathrm{mmol} / \mathrm{kg}$ soil and were statistically significant in 11 samples.
\end{abstract}

Index words: reaction heat, oxalate-extractable $\mathrm{Al}$ and $\mathrm{Fe}$, sorption equilibrium, temperature

\section{Introduction}

In a previous study on seven mineral soils (NISKANEN 1990), the rise of temperature from $+5^{\circ} \mathrm{C}$ to $+20^{\circ} \mathrm{C}$ increased the sorption of phosphate from high $\mathrm{P}$ concentrations but the sorption from low phosphate concentrations was not significantly dependent on temperature. There the effect of rise in temperature on the sorption from high phosphate concentration may have been due to accelerated diffusion which increased the migration of phosphate onto the sorption surfaces of soil. HARTIKAINEN (1979) found that the effect of the rise in temperature on sorption from low phosphate concentrations was slightly positive, negative or nonexistent. Because the soil material in the above studies was limited and the results were contradictory, the aim of this paper was to study in a larger soil material the effect of temperature on phosphate sorption from a low $\mathrm{P}$ concentration.

\section{Material and methods}

The material was collected at 23 sampling sites, and it consisted of 16 surface soil samples and 17 samples from deeper soil layers (Table 1). At 10 sampling sites, both surface and deeper layer samples were taken. The samples were air-dried and ground to pass a 2-mm sieve. Soil pH was measured in soil$0.01 \mathrm{M} \mathrm{CaCl}_{2}$ suspension $(1: 2.5 \mathrm{v} / \mathrm{v})$. The organic carbon content was determined by 
Table 1. Soil samples.

\begin{tabular}{|c|c|c|c|c|c|c|c|c|c|c|}
\hline \multirow{3}{*}{$\begin{array}{l}\text { Sample } \\
\text { No. }\end{array}$} & \multirow{3}{*}{ Locality } & \multirow{3}{*}{$\begin{array}{l}\text { Sampling } \\
\text { depth, cm }\end{array}$} & \multirow{3}{*}{$\begin{array}{c}\mathrm{pH} \\
\left(\mathrm{CaCl}_{2}\right)\end{array}$} & \multirow{3}{*}{$\underset{\%}{\text { Organic } C,}$} & \multirow{2}{*}{\multicolumn{3}{|c|}{$\begin{array}{l}\text { Particle-size distribution } \\
(\mu \mathrm{m}), \%\end{array}$}} & \multicolumn{3}{|c|}{ Oxalate-extractable } \\
\hline & & & & & & & & $\mathrm{Fe}$ & $\mathrm{Al}$ & \multirow[t]{2}{*}{$\mathrm{Fe} / \mathrm{Al}$} \\
\hline & & & & & $<2$ & $2-20$ & $>20$ & \multicolumn{2}{|c|}{$\mathrm{mmol} / \mathrm{kg}$ soil } & \\
\hline 1 & Vaala & $20-40$ & 4.2 & 2.8 & 3 & 16 & 81 & 60 & 33 & 1.8 \\
\hline 2 & Hyvinkäă & $0-20$ & 4.5 & 3.3 & 4 & 12 & 84 & 93 & 186 & 0.5 \\
\hline 3 & Turenki & $30-60$ & 6.9 & 0.9 & 5 & 15 & 80 & 40 & 101 & 0.4 \\
\hline $4 a$ & $"$ & $0-30$ & 5.6 & 3.5 & 7 & 18 & 75 & 59 & 111 & 0.5 \\
\hline $4 b$ & $"$ & $30-60$ & 7.2 & 1.0 & 4 & 18 & 78 & 35 & 101 & 0.3 \\
\hline $5 a$ & $n$ & $0-30$ & 6.2 & 2.7 & 8 & 23 & 69 & 53 & 103 & 0.5 \\
\hline $5 b$ & $"$ & $30-60$ & 6.5 & 0.7 & 6 & 24 & 70 & 31 & 78 & 0.4 \\
\hline $6 a$ & Naantali & $0-30$ & 7.3 & 1.6 & 10 & 7 & 83 & 65 & 32 & 2.0 \\
\hline $6 b$ & $n$ & $30-60$ & 7.1 & 0.7 & 7 & 5 & 88 & 53 & 19 & 2.7 \\
\hline 7 & Imatra & $20-40$ & 4.8 & 3.7 & 14 & 19 & 67 & 57 & 137 & 0.4 \\
\hline 8 & Hyvinkäaa & $0-20$ & 5.0 & 3.7 & 15 & 24 & 61 & 66 & 106 & 0.6 \\
\hline $9 \mathrm{a}$ & Naantali & $0-30$ & 7.2 & 2.3 & 19 & 14 & 67 & 70 & 19 & 3.8 \\
\hline $9 b$ & $n$ & $30-60$ & 6.6 & 1.7 & 28 & 20 & 52 & 75 & 40 & 1.9 \\
\hline $10 \mathrm{a}$ & $"$ & $0-30$ & 6.2 & 2.8 & 20 & 15 & 65 & 103 & 38 & 2.7 \\
\hline $10 \mathrm{~b}$ & $"$ & $30-60$ & 5.9 & 1.6 & 22 & 14 & 64 & 96 & 34 & 2.8 \\
\hline $11 \mathrm{a}$ & Salo & $0-30$ & 7.1 & 3.1 & 20 & 31 & 49 & 92 & 42 & 2.2 \\
\hline $11 \mathrm{~b}$ & " & $30-60$ & 6.9 & 2.3 & 32 & 17 & 51 & 100 & 40 & 2.5 \\
\hline 12 & Rajamäki & $0-20$ & 5.2 & 3.0 & 23 & 25 & 52 & 66 & 44 & 1.5 \\
\hline 13 & Säkylä & $0-30$ & 7.2 & 14.6 & 25 & 43 & 32 & 67 & 130 & 0.5 \\
\hline $14 \mathrm{a}$ & Salo & $0-30$ & 6.6 & 2.4 & 26 & 18 & 56 & 76 & 33 & 2.3 \\
\hline $14 \mathrm{~b}$ & " & $30-60$ & 5.9 & 1.3 & 45 & 27 & 28 & 91 & 42 & 2.2 \\
\hline $15 \mathrm{a}$ & Säkylä & $0-30$ & 7.0 & 3.1 & 27 & 42 & 31 & 168 & 32 & 5.2 \\
\hline $15 b$ & $"$ & $30-60$ & 6.1 & 1.5 & 30 & 45 & 25 & 180 & 30 & 6.1 \\
\hline $16 a$ & Salo & $0-30$ & 6.7 & 2.7 & 28 & 10 & 62 & 79 & 42 & 1.9 \\
\hline $16 \mathrm{~b}$ & " & $30-60$ & 6.3 & 1.6 & 48 & 10 & 42 & 89 & 49 & 1.8 \\
\hline 17 & Säkylä & $30-60$ & 5.5 & 1.4 & 29 & 45 & 26 & 182 & 36 & 5.1 \\
\hline 18 & Imatra & $20-40$ & 5.4 & 3.2 & 33 & 39 & 28 & 77 & 62 & 1.3 \\
\hline 19 & Hyvinkảä & $0-20$ & 5.3 & 1.9 & 36 & 36 & 28 & 53 & 53 & 1.0 \\
\hline 20 & Viikki & $20-40$ & 5.6 & 1.7 & 45 & 19 & 36 & 162 & 68 & 2.4 \\
\hline 21 & Nurmijărvi & $20-40$ & 4.1 & 2.9 & 45 & 45 & 10 & 134 & 99 & 1.4 \\
\hline 22 & Salo & $0-30$ & 6.5 & 4.4 & 46 & 27 & 27 & 64 & 56 & 1.2 \\
\hline $23 a$ & Anjala & $0-30$ & 6.1 & 2.5 & 48 & 29 & 23 & 72 & 56 & 1.3 \\
\hline $23 \mathrm{~b}$ & " & $30-60$ & 6.0 & 2.0 & 54 & 25 & 21 & 70 & 56 & 1.3 \\
\hline $\bar{x}$ & & & 6.1 & 2.7 & 25 & 24 & 52 & 84 & 64 & 1.9 \\
\hline s & & & 0.9 & 2.3 & 15 & 12 & 23 & 40 & 39 & 1.5 \\
\hline range & & & $4.1-7.3$ & $0.7-14.6$ & $3-54$ & $5-45$ & $10-88$ & $31-182$ & $19-186$ & $0.3-6.1$ \\
\hline
\end{tabular}

a modified ALten wet combustion method (Graham 1948). The particle-size distribution of the inorganic matter was determined by the pipette method (ELONEN 1971). Aluminium and iron were extracted by $0.05 \mathrm{M}$ ammonium oxalate ( $\mathrm{pH} 2.9$, ratio 1:20 w/v, shaking time 2 h) (NISKANEN 1989), and determined by atomic absorption spectrophotometry.

To determine the phosphate sorption, $5 \mathrm{~g}$ of soil was treated at $+5^{\circ} \mathrm{C}$ and $+20^{\circ} \mathrm{C}$ for 2 days with $100 \mathrm{ml}$ of solution containing
$\mathrm{KH}_{2} \mathrm{PO}_{4} 0.1 \mathrm{mmol} / \mathrm{l}$. The ionic strength of the solution was adjusted with $\mathrm{KCl}$ to 0.01 . To inhibit microbial activity, the solution contained $0.01 \% \mathrm{NaN}_{3}$. The suspensions were shaken daily for 8 hours. The $\mathrm{pH}$ of suspensions was measured at the beginning and the end of the experiment. The phosphorus concentration of the filtrates was determined by a modified molybdenum blue method (KAILA 1955). The amount of retained phosphate was calculated as the difference between the phos- 
phate present initially and that remained in the supernatant. The experiment was carried out in duplicate.

\section{Results and discussion}

The initial $\mathrm{pH}$ of soil suspensions was 5.07.8 , and after the sorption of 2 days, $\mathrm{pH}$ rose or decreased slightly in most cases, generally by no more than $0.5 \mathrm{pH}$ units. On the aver-

Table 2. Sorption of $\mathrm{P}$ in experimental soils.

\begin{tabular}{|c|c|c|c|}
\hline \multirow[t]{2}{*}{$\begin{array}{l}\text { Sample } \\
\text { No. }\end{array}$} & \multicolumn{2}{|c|}{$\begin{array}{l}\text { Sorption of } \mathrm{P} \\
\text { at }+20^{\circ} \mathrm{C}\end{array}$} & \multirow{2}{*}{$\begin{array}{c}\text { Change in sorption } \\
\text { of } \mathrm{P} \text { with a drop } \\
\text { in temperature } \\
\text { to }+5^{\circ} \mathrm{C}, \\
\mathrm{mmol} / \mathrm{kg} \text { soil }\end{array}$} \\
\hline & $\underset{\text { soil }}{\mathrm{mmol} / \mathrm{kg}}$ & $\begin{array}{c}\% \text { of } \\
\text { addition }\end{array}$ & \\
\hline 1 & 1.30 & 65 & $0.13^{*}$ \\
\hline 2 & 2.00 & 100 & $0.00^{\mathrm{ns}}$ \\
\hline 3 & 1.94 & 97 & $0.01^{\mathrm{ns}}$ \\
\hline $4 a$ & 1.76 & 88 & $0.06^{*}$ \\
\hline $4 b$ & 1.91 & 95 & $0.02^{\mathrm{ns}}$ \\
\hline $5 a$ & 1.89 & 94 & $0.04^{*}$ \\
\hline $5 b$ & 1.93 & 97 & $0.04^{*}$ \\
\hline $6 a$ & 0.80 & 40 & $-0.03^{\mathrm{ns}}$ \\
\hline $6 b$ & 1.18 & 59 & $0.21^{\text {ns }}$ \\
\hline 7 & 1.97 & 98 & $0.01^{\mathrm{ns}}$ \\
\hline 8 & 1.99 & 99 & $0.01^{\mathrm{ns}}$ \\
\hline $9 \mathrm{a}$ & 0.69 & 34 & $0.10^{\mathrm{ns}}$ \\
\hline $9 b$ & 1.41 & 71 & $0.14^{\mathrm{ns}}$ \\
\hline $10 \mathrm{a}$ & 0.71 & 35 & $0.02^{\mathrm{ns}}$ \\
\hline $10 \mathrm{~b}$ & 1.38 & 69 & $0.13^{\mathrm{ns}}$ \\
\hline $11 \mathrm{a}$ & 0.69 & 35 & $0.17^{\text {ns }}$ \\
\hline $11 \mathrm{~b}$ & 1.64 & 82 & $0.05^{\mathrm{ns}}$ \\
\hline 12 & 1.53 & 77 & $0.22^{*}$ \\
\hline 13 & 1.87 & 94 & $0.00^{\mathrm{ns}}$ \\
\hline $14 \mathrm{a}$ & 1.12 & 56 & $0.15^{\text {ns }}$ \\
\hline $14 b$ & 1.80 & 90 & $0.06^{\mathrm{ns}}$ \\
\hline $15 \mathrm{a}$ & 0.91 & 46 & $0.13^{*}$ \\
\hline $15 b$ & 1.68 & 84 & $0.12^{\mathrm{ns}}$ \\
\hline $16 \mathrm{a}$ & 0.50 & 25 & $0.29^{*}$ \\
\hline $16 \mathrm{~b}$ & 1.83 & 92 & $0.05^{*}$ \\
\hline 17 & 1.81 & 91 & $0.10^{* * *}$ \\
\hline 18 & 1.22 & 61 & $0.21^{\mathrm{ns}}$ \\
\hline 19 & 1.61 & 80 & $0.25^{* * *}$ \\
\hline 20 & 1.92 & 96 & $0.05^{\mathrm{ns}}$ \\
\hline 21 & 2.00 & 100 & $0.00^{\mathrm{ns}}$ \\
\hline 22 & 1.67 & 83 & $0.07^{\mathrm{ns}}$ \\
\hline $23 a$ & 1.63 & 81 & $0.07^{\mathrm{ns}}$ \\
\hline $23 \mathrm{~b}$ & 1.79 & 90 & $0.07^{*}$ \\
\hline$\overline{\mathrm{x}}$ & 1.52 & 76 & 0.09 \\
\hline s & 0.46 & & 0.08 \\
\hline range & $0.50-2.00$ & & $-0.03-0.29$ \\
\hline
\end{tabular}

age, experimental soils sorbed three quarters of the added phosphorus (Table 2). There were 14 samples which sorbed $90 \%$ or more of the added phosphorus.

The sorption of phosphate tended to be higher in most soils at the temperature of $+5^{\circ} \mathrm{C}$ than at $+20^{\circ} \mathrm{C}$ (Table 2). The difference was statistically significant in 11 samples. In the study of HARTIKAINEN (1979) on a material of six soil samples, there was also a tendency for the phosphate sorption to be higher at $+5^{\circ} \mathrm{C}$ than at $+20^{\circ} \mathrm{C}$, when sorption occurred from a P concentration of $0.02 \mathrm{mmol} / 1$ during 24 hours. From the $\mathrm{P}$ concentration of $0.06 \mathrm{mmol} / 1$, two soils sorbed $\mathrm{P}$ more at $+5^{\circ} \mathrm{C}$ than at $+20^{\circ} \mathrm{C}$. However, the response to changes in temperature was slight. The minor effect of temperature is due to the small change in the standard enthalpy in the adsorption of phosphate and the principal dependence of adsorption equilibrium on the changes in entropy (AURA 1980).

In many studies concerning the effect of temperature on phosphate sorption on soils and oxides, the sorption has been shown to increase with a rise in temperature (e.g. Muljadi et al. 1966, Kuo and Lotse 1974, HartiKainen 1979). There are, however, some investigations in which phosphate sorption is reported to be exothermic (e.g. BARRow 1979). These opposite results may be explained by the different responses to changes in temperature in sorption from low and high anion concentration. There are two phases in the sorption of phosphate and other weak acid anions retained through ligand exchange. The first one, the sorption from low anion concentration is relatively insensitive to changes in temperature. The minor effect may be positive, negative or nonexistent. In the second phase, the sorption from high anion concentration increases with rising temperature. In the study of REYES and JURINAK (1967) on adsorption of molybdate on iron oxide (hematite), the first phase of sorption continued until the concentration of molybdate in the equilibrium solution was about $0.1 \mathrm{mmol} / 1$. Thereafter the sorption increased with rising tem- 
perature. The probable explanation for the effect of temperature on the sorption from high anion concentration may be that the increase in sorption is due to an increased rate of diffusion and migration of phosphate into fine pores of hydrous oxides.

\section{References}

AurA, E. 1980. Oxygen as exchangeable ligand in soil. J. Scient. Agric. Soc. Finl. 52: 34-44.

Barrow, N.J. 1979. Three effects of temperature on the reactions between inorganic phosphate and soil. J. Soil Sci. 30: 271-279.

Elonen, P. 1971. Particle-size analysis of soil. Acta Agr. Fenn. 122: 1-122.

Graham, E.R. 1948. Determination of soil organic matter by means of a photoelectric colorimeter. Soil Sci. 65: $181-183$.

Hartikainen, H. 1979. Phosphorus and its reactions in terrestrial soils and lake sediments. J. Scient. Agric. Soc. Finl. 51: 537-624.

Kalla, A. 1955. Studies on the colorimetric determination of phosphorus in soil extracts. Acta Agr. Fenn. 83: $25-47$.

Kuo, S. \& Lotse, E.G. 1974. Kinetics of phosphate ad- sorption and desorption by lake sediments. Soil Sci. Soc. Amer. Proc. 38: 50-54.

Muljadi, D., Posner, A.M. \& Quirk, J.P. 1966. The mechanism of phosphate adsorption by kaolinite, gibbsite, and pseudoboehmite. Part III. The effect of temperature on adsorption. J. Soil Sci. 17: 238-247.

NiSKANEN, R. 1989. Extractable aluminium, iron and manganese in mineral soils. III Comparison of extraction methods. J. Agric. Sci. Finl. 61: 89-97.

- 1990. Sorption capacity of phosphate in mineral soils. I Estimation of sorption capacity by means of sorption isotherms. J. Agric. Sci. Finl. 62: 1-8.

ReYes, E.D. \& JurinaK, J.J. 1967. A mechanism of molybdate adsorption on $\alpha-\mathrm{Fe}_{2} \mathrm{O}_{3}$. Soil Sci. Soc. Amer. Proc. 31: 637-641.

Ms received August 25, 1989

\section{SELOSTUS}

\section{Lämpötilan vaikutus fosfaatin pidättymiseen kivennäismaihin}

\section{Raina Niskanen \\ Maanviljelyskemian laitos, Helsingin yliopisto, 00710 Helsinki}

Lämpötilan vaikutusta fosfaatin pidättymiseen tutkittiin 33:lla kivennäismaalla. Reaktio tapahtui 2 vuorokauden aikana lämpötiloissa $+5^{\circ} \mathrm{C} \mathrm{ja}+20^{\circ} \mathrm{C}$. Reaktioliuoksessa oli fosfaattia $0,1 \mathrm{mmol} / 1$ (ionivahvuus 0,01 ). Lämpötilassa $+20^{\circ} \mathrm{C}$ pidättyi fosfaattia $0,5-2,0 \mathrm{mmol} / \mathrm{kg}$

maata. Lämpötilassa $+5^{\circ} \mathrm{C}$ fosfaattia pidättyi saman verran tai vähän enemmän kuin $+20^{\circ} \mathrm{C}$ :ssa. Ero $(-0,03-$ $0,29 \mathrm{mmol} / \mathrm{kg}$ maata) oli tilastallisesti merkitsevä 11 maanăytteessă. 